\title{
Work Plan: Targeted Investigation to Assess Current Conditions Associated with the Carbon Tetrachloride Plume Downgradient from the Former CCC/USDA Facility at Milford, Nebraska
}

Environmental Science Division 


\begin{abstract}
About Argonne National Laboratory
Argonne is a U.S. Department of Energy laboratory managed by UChicago Argonne, LLC under contract DE-AC02-06CH11357. The Laboratory's main facility is outside Chicago, at 9700 South Cass Avenue, Argonne, Illinois 60439. For information about Argonne, see www.anl.gov.
\end{abstract}

\title{
Availability of This Report
}

This report is available, at no cost, at http://www.osti.gov/bridge. It is also available on paper to the U.S. Department of Energy and its contractors, for a processing fee, from:

U.S. Department of Energy

Office of Scientific and Technical Information

P.O. Box 62

Oak Ridge, TN 37831-0062

phone (865) 576-8401

fax (865) 576-5728

reports@adonis.osti.gov

\section{Disclaimer}

This report was prepared as an account of work sponsored by an agency of the United States Government. Reference herein to any specific commercial product, process, or service by trade name, trademark, manufacturer, or otherwise, does not necessarily constitute or imply its endorsement, recommendation, or favoring by the United States Government or any agency thereof. The views and opinions of document authors expressed herein do not necessarily state or reflect those of the United States Government or any agency thereof, Argonne National Laboratory, or UChicago Argonne, LLC. 


\section{Work Plan: Targeted Investigation to Assess Current Conditions Associated with the Carbon Tetrachloride Plume Downgradient from the Former CCC/USDA Facility at Milford, Nebraska}

by

Applied Geosciences and Environmental Management Section

Environmental Science Division, Argonne National Laboratory

July 2008 


\section{Contents}

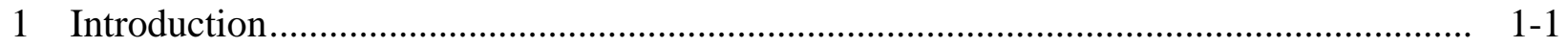

2 Summary of Previous Investigations ........................................................................... 2-1

3 Proposed Investigation....................................................................................... 3-1

3.1 Technical Objectives................................................................................... 3-1

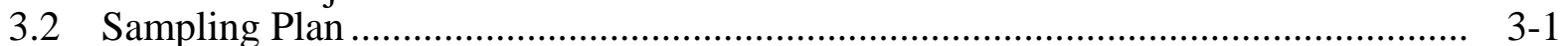

3.2.1 Groundwater Sampling ................................................................... 3-2

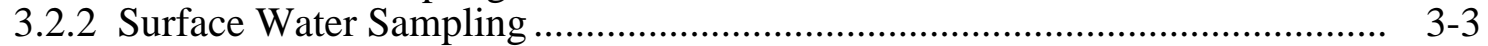

3.3 Health and Safety Plan..................................................................................... 3-3

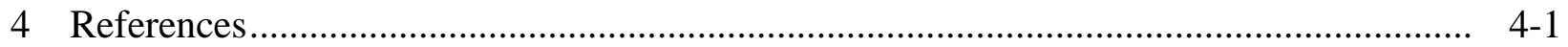

Appendix A: Summary of Investigations in 1999-2003 at the Former CCC/USDA Grain Storage Facility at Milford, Nebraska................................................................ A-1

\section{Figures}

1.1 Location of the former CCC/USDA facility in relation to the town of Milford and the Trojan and Troyer wells.

2.1 Maximum carbon tetrachloride concentrations in groundwater and surface water samples collected during in the 2001-2003 sampling events of the Phase II Investigation at Milford

2.2 Maximum chloroform concentrations in groundwater and surface water samples collected during the 2001-2003 sampling events of the Phase II Investigation at Milford

3.1 Groundwater elevations at Milford in December 2003

3.2 Sampling locations proposed to accomplish the targeted investigation's technical objective of plume delineation

3.3 Route to Memorial Hospital in Seward, Nebraska 


\section{Figures (Cont.)}

A.1 Analytical results for shallow soil samples collected during the Interim Phase II investigation.

A.2 Analytical results for subsurface soil samples collected during the Interim Phase II investigation........................................................................................................ A-10

A.3 Maximum carbon tetrachloride concentrations in groundwater samples collected at Milford in 1999, 2001, and 2003, displayed on a west-to-east hydrogeologic cross section running along the axis of the most contaminated part of the plume. 


\section{Work Plan: Targeted Investigation to Assess Current Conditions Associated with the Carbon Tetrachloride Plume Downgradient from the Former CCC/USDA Facility at Milford, Nebraska}

\section{Introduction}

The Commodity Credit Corporation of the U.S. Department of Agriculture (CCC/USDA) formerly operated a grain storage facility at Milford, Nebraska. In May 2008, the CCC/USDA directed the Environmental Science Division of Argonne National Laboratory, as its technical consultant, to develop a work plan for a targeted investigation at the Milford site. The purpose of the targeted investigation is to assess the current extent and configuration of the carbon tetrachloride plume downgradient from the former CCC/USDA facility and proximal to the banks of the Big Blue River, which borders the area of concern to the east, southeast, and northeast.

In 1995, carbon tetrachloride contamination was detected by the Nebraska Department of Health and Human Services in a private drinking water well and a livestock well $1.25 \mathrm{mi}$ south of Milford (Figure 1.1). The Trojan drinking water well is located directly downgradient (approximately $300 \mathrm{ft}$ east) of the former CCC/USDA facility. Low levels of carbon tetrachloride contamination were also found in the Troyer livestock well, approximately 1,200 ft north of the former CCC/USDA facility. 


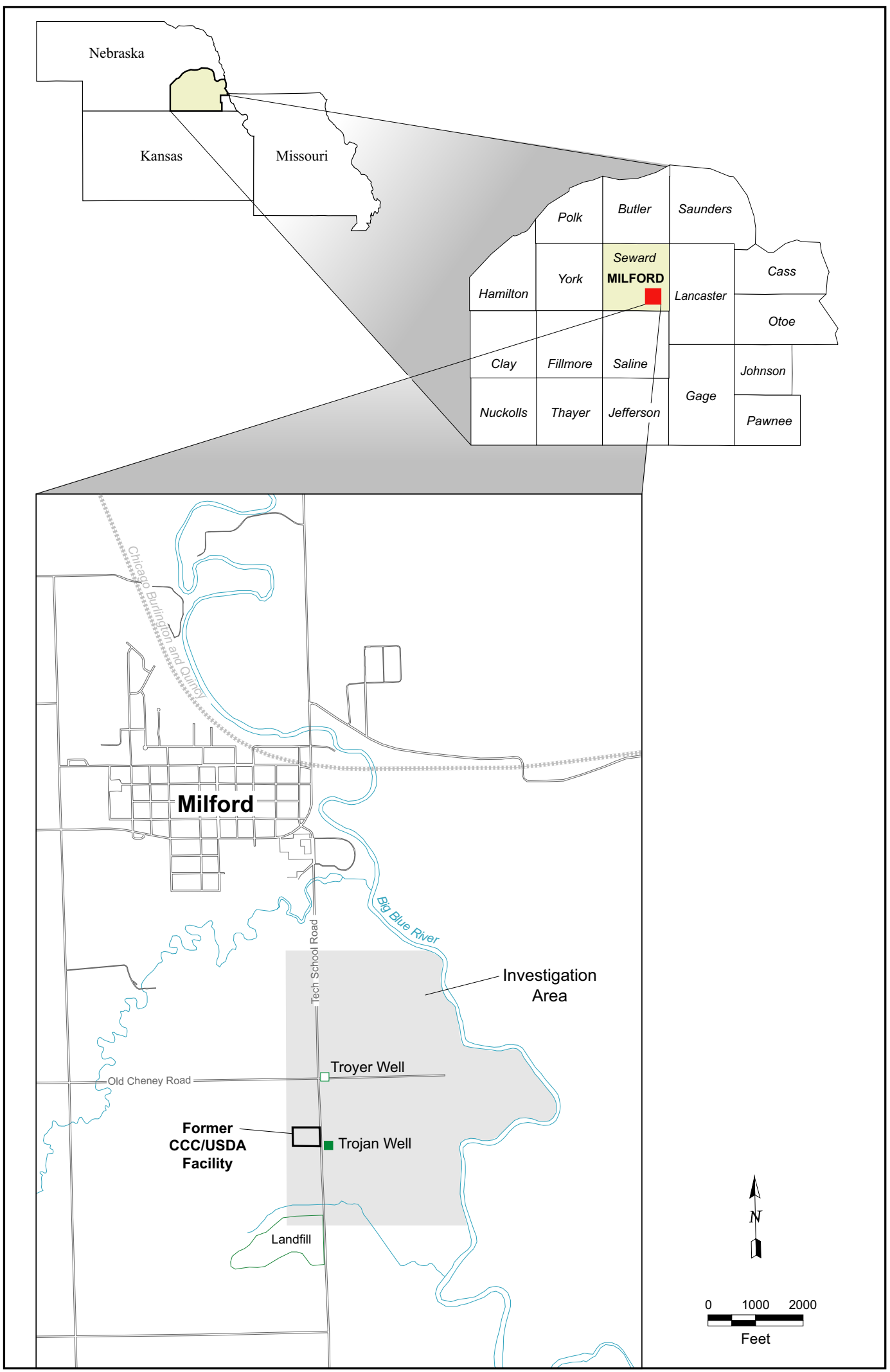

FIGURE 1.1 Location of the former CCC/USDA facility in relation to the town of Milford and the Trojan and Troyer wells. 


\section{Summary of Previous Investigations}

A series of investigations was conducted in 1999-2003 to confirm the source of the contamination found in the Trojan drinking water well and to define the extent and nature of any possible downgradient carbon tetrachloride plume emanating from the former CCC/USDA facility. A summary of the historical investigations and reports completed during the Milford site characterization is in Appendix A, along with a summary of analytical results generated during the investigations. The most recent study of the Milford site was an investigation in December 2003 focusing on the Gerry Dunlap property and adjacent properties (Argonne 2004a).

Figure 2.1 illustrates the maximum carbon tetrachloride concentrations in the groundwater and surface water samples recovered during previous sampling events. Significant levels of carbon tetrachloride were observed during these events, with concentrations of 2,172 $\mu \mathrm{g} / \mathrm{L}$ (September 1999) and 1,728 $\mu \mathrm{g} / \mathrm{L}$ (2003). Figure 2.2 illustrates the maximum chloroform values associated with previous sampling events. Chloroform values of $167 \mu \mathrm{g} / \mathrm{L}$ (2001) and $459 \mu \mathrm{g} / \mathrm{L}$ (2003) were observed. Chloroform values at such elevated levels strongly suggest the influence of active reductive dechlorination and natural degradation of carbon tetrachloride.

Monitoring of the carbon tetrachloride concentrations and downgradient migration was discontinued when litigation was brought against the CCC/USDA by Gerry Dunlap. Work effectively stopped at the site until the litigation was completed on May 18, 2006. The case was heard and settled in the U.S. District Court for the District of Nebraska. The court found in favor of the CCC/USDA. 


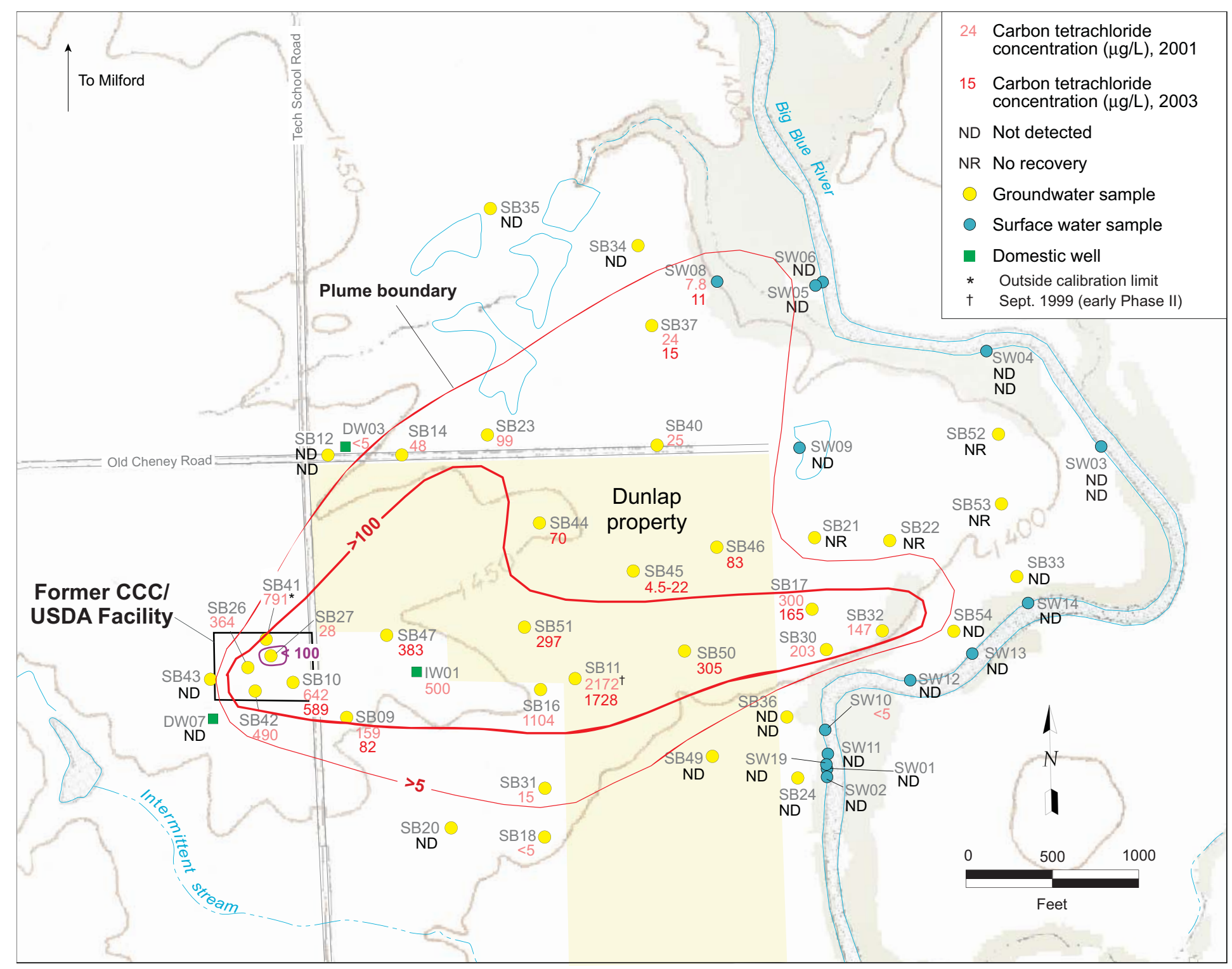

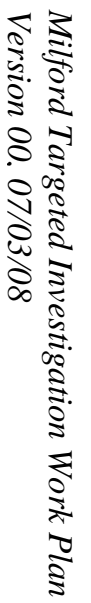

FIGURE 2.1 Maximum carbon tetrachloride concentrations in groundwater and surface water samples collected during the 2001-2003 sampling events of the Phase II Investigation at Milford. 


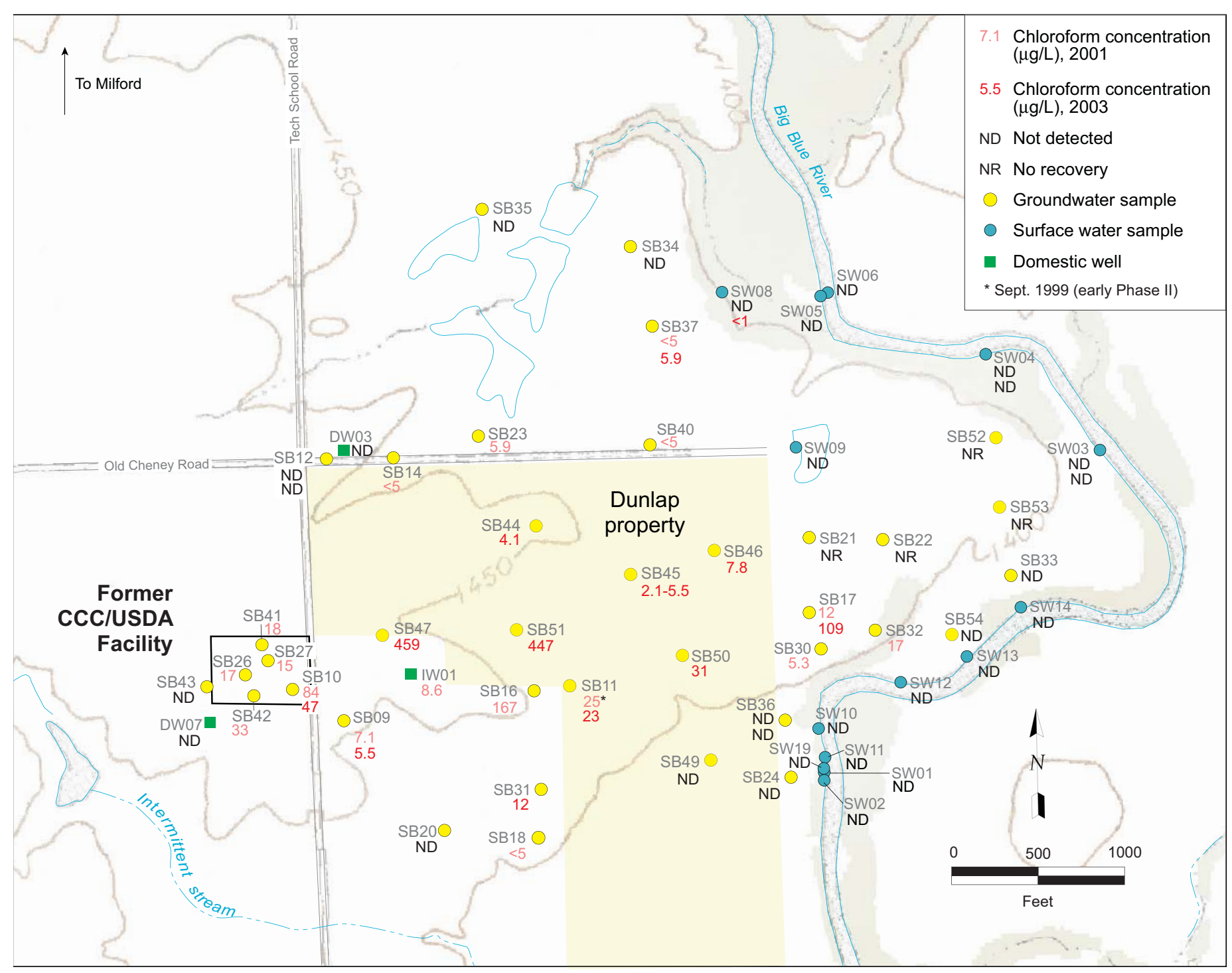

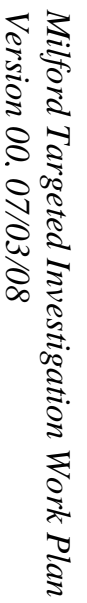

FIGURE 2.2 Maximum chloroform concentrations in groundwater and surface water samples collected during the 2001-2003 sampling events of the Phase II Investigation at Milford. 


\section{Proposed Investigation}

\subsection{Technical Objectives}

The proposed 2008 targeted investigation is designed — to the extent possible, given the present access restrictions - to accomplish the following technical objectives:

- Identify the present location, configuration, and downgradient extent of the carbon tetrachloride plume emanating from the former CCC/USDA facility.

- Determine whether the plume has traveled in the subsurface from the position identified in late 2003 and is emerging to the surface through groundwater seeps bordering the western bank of the Big Blue River.

- Assess whether the carbon tetrachloride contamination has reached the Big Blue River and represents any potential risk to human health.

The results of the 2003 investigation form the basis for the current proposed work plan. The 1999-2003 carbon tetrachloride concentrations and their distributions will be compared with the results from the proposed 2008 targeted investigation to determine whether the carbon tetrachloride concentrations are increasing or decreasing, the plume configuration is changing, and the plume is continuing to move toward the Big Blue River.

\subsection{Sampling Plan}

The sampling event proposed to accomplish the technical objectives in Section 3.1 will focus on the previously identified limits of the carbon tetrachloride and chloroform plumes (Figures 2.1 and 2.2). Groundwater elevation data from previous investigations at the site are illustrated in Figure 3.1. The distribution of sampling locations for the proposed targeted investigation is presented in Figure 3.2.

Modifications to the proposed sampling plan may be required on the basis of access considerations and field conditions. As the investigation proceeds, samples will be shipped via overnight delivery service for analysis at the Applied Geosciences and Environmental 
Management Laboratory at Argonne. As the analytical results are received, it may become necessary to expand the investigation in order to achieve the stated technical objective of plume delineation. Decisions to alter the work plan will be made in the field as the sampling progresses, with the concurrence of the CCC/USDA.

\subsubsection{Groundwater Sampling}

A series of cone penetrometer and/or Geoprobe pushes will be made to the appropriate depth to reach groundwater at the locations indicated in Figure 3.2. At this depth, a groundwater sample will be retrieved in each boring per the procedure outlined in the Nebraska Master Work Plan (Argonne 2002a). Groundwater elevation data from previous investigations at the site (Figure 3.1), together with allowances for shallower groundwater levels due to recent persistent heavy rains, suggest that sampling depths of approximately 40-70 ft BGL (below ground level) can be anticipated.

In addition to the direct-push locations, groundwater samples will be collected from the two existing monitoring wells remaining in the Milford network (SB12 and SB09), from the Trojan drinking water well (DW05) and the Troyer livestock well (DW03), and from seeps identified previously along the western and southwestern banks of the Big Blue River (Figure 3.2).

The proposed 2008 targeted investigation groundwater sampling plan includes the following locations and sources of samples, as illustrated in Figure 3.2:

- Nine direct-push locations distributed along the eastern margin of the plume (as defined in 2003; Figure 2.1). These locations, selected to coincide with the previously identified margins or extent of the carbon tetrachloride plume (2003), should provide information regarding current carbon tetrachloride concentrations and possible eastward plume movement toward the Big Blue River.

- Nine direct-push locations located as follows: (1) three locations along the northern boundary of the Dunlap property, along Old Cheney Road; (2) four locations along the southern and southwestern boundaries of the Dunlap 
property; (3) a single location within the previously identified plume, along the eastern boundary of the Dunlap property; and (4) a single location on the former CCC/USDA facility. The earlier litigation precludes sampling on the Dunlap property, despite the fact that the axis of the carbon tetrachloride plume runs directly through that property.

- One existing private drinking water well on the Trojan property (DW05) and one private livestock well on the Troyer property (DW03) will be sampled as permanent monitoring points.

- Two existing monitoring wells - SB09 (on the Trojan property) and SB12 (along Old Cheney Road) — will be sampled as permanent monitoring points.

- Eight samples to be collected at locations as close as possible to previously identified seeps sampled during the 2001 and 2003 investigations. Alternate locations will be selected if the original seeps cannot be found or if conditions have changed enough so that these seeps are no longer actively flowing to the river.

\subsubsection{Surface Water Sampling}

A total of eight surface water samples will be collected, as follows (Figure 3.2):

- Samples will be retrieved from the Big Blue River at seven locations.

- A single sample will be collected from a pond on the Troyer property, located near the northeastern boundary of the previously identified possible northeastern lobe of the carbon tetrachloride plume.

\subsection{Health and Safety Plan}

The general provisions of Section 3 of the Nebraska Master Work Plan (Argonne 2002a) will apply to the work at Milford. In addition, a site-specific health and safety plan will be 
developed and approved by the Argonne field safety coordinator. The site-specific plan will be brought to the site for reference during the investigation. The route from the work site to the nearest hospital is illustrated in Figure 3.3. 


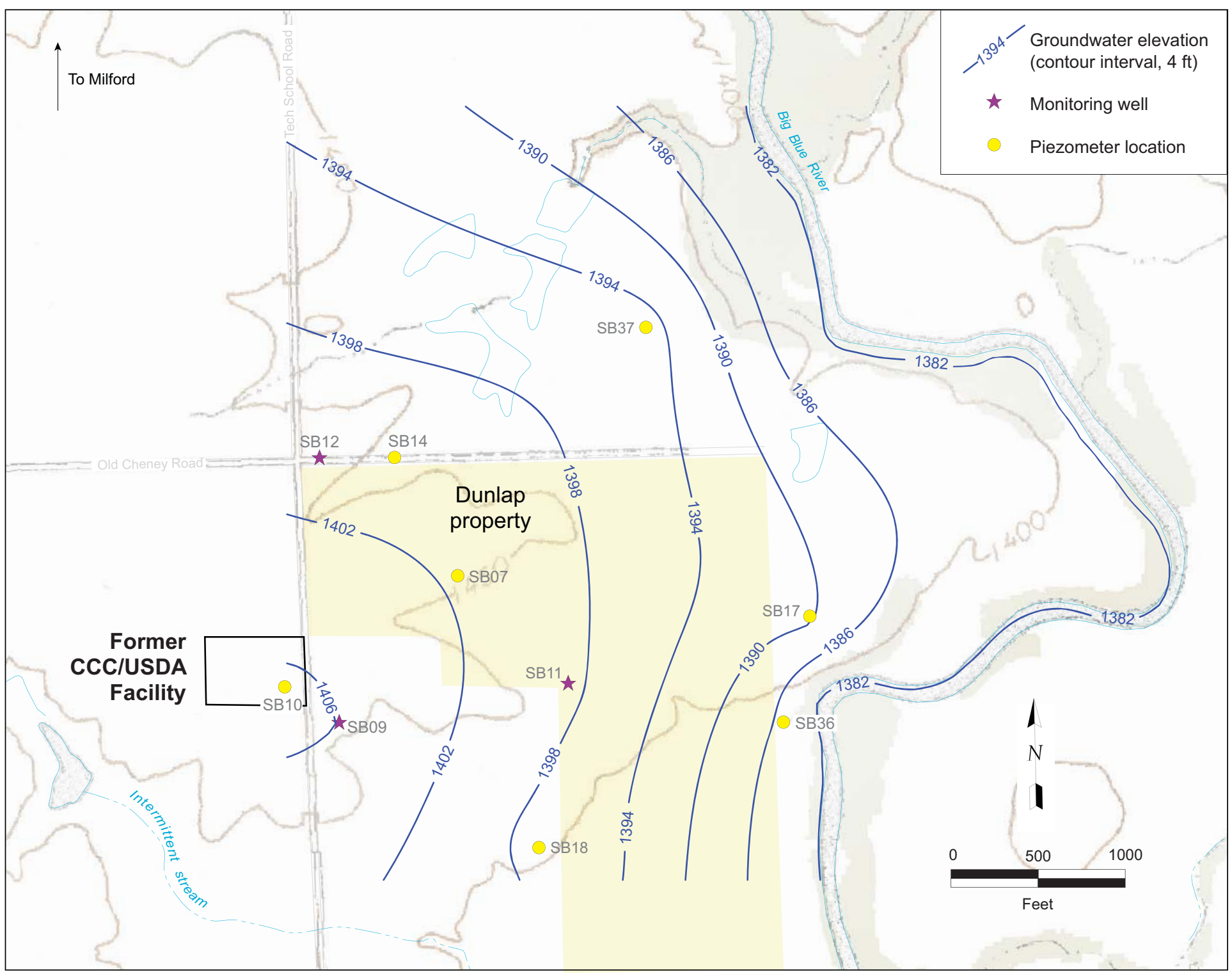

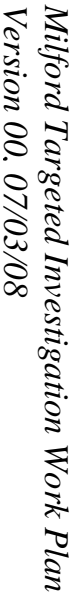

FIGURE 3.1 Groundwater elevations (feet above mean sea level) at Milford in December 2003. 


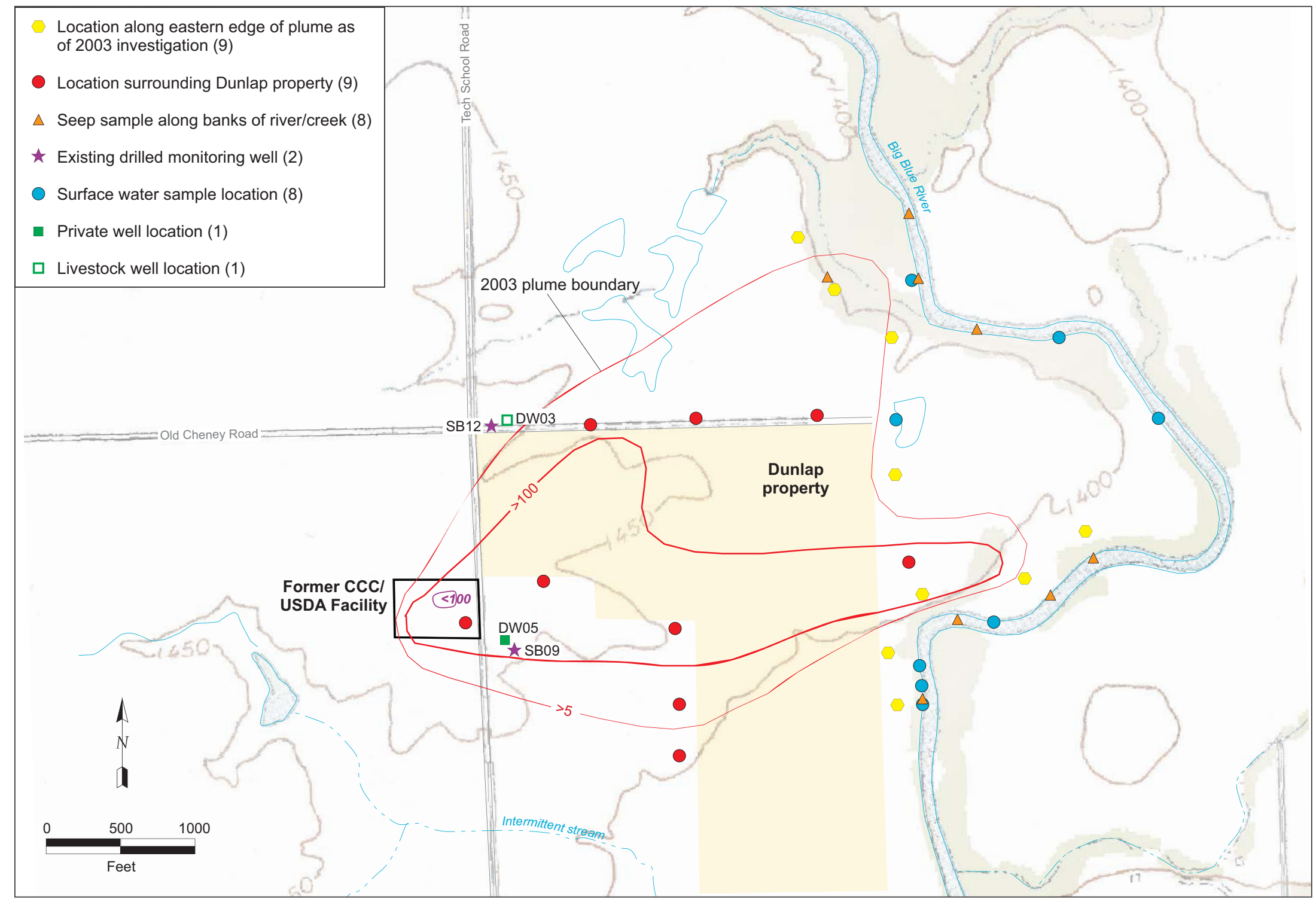

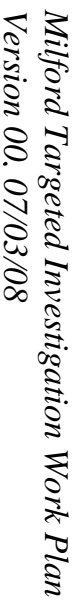

FIGURE 3.2 Sampling locations proposed to accomplish the targeted investigation's technical objective of plume delineation. 


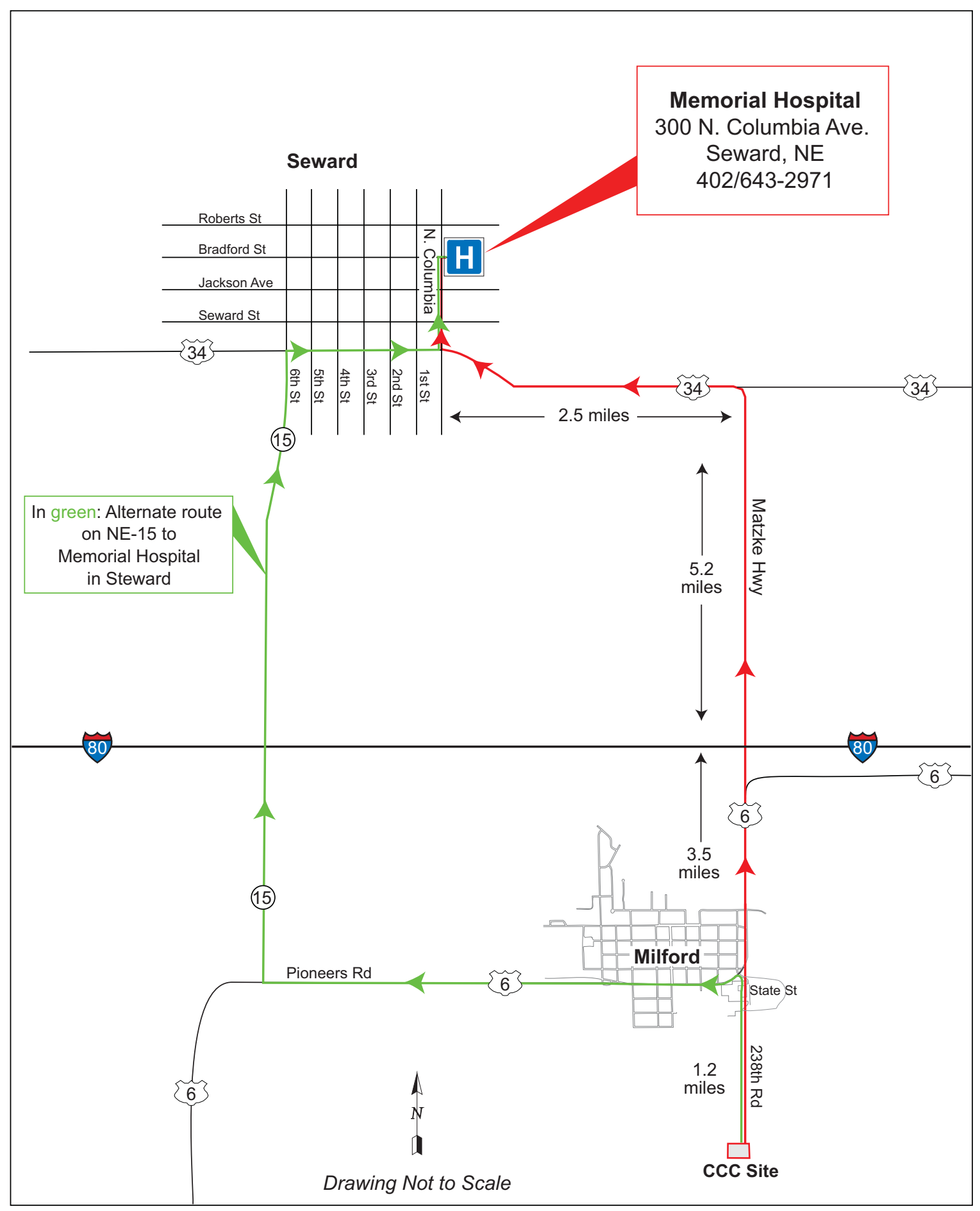

FIGURE 3.3 Route to Memorial Hospital in Seward, Nebraska. 


\section{References}

Argonne, 1999, Final Work Plan: Phase I QuickSite ${ }^{S M}$ Investigation, Milford, Nebraska, prepared for the Commodity Credit Corporation, U.S. Department of Agriculture, Washington, D.C., by Argonne National Laboratory, Argonne, Illinois, July.

Argonne, 2000, Final Phase I Report and Phase II Work Plan: QuickSite ${ }^{S M}$ Investigation, Milford, Nebraska, prepared for the Commodity Credit Corporation, U.S. Department of Agriculture, Washington, D.C., by Argonne National Laboratory, Argonne, Illinois, January.

Argonne, 2002a, Final Master Work Plan: Environmental Investigations at Former CCC/USDA Facilities in Nebraska, 2002 Revision, ANL/ER/TR-02/003, prepared for the commodity Credit Corporation, U.S. Department of Agriculture, Washington, D.C., by Argonne National Laboratory, Argonne, Illinois, December.

Argonne, 2002b, Final Phase II Interim Report: QuickSite ${ }^{S M}$ Investigation, Milford, Nebraska, ANL/ER/TR-02/005, prepared for the Commodity Credit Corporation, U.S. Department of Agriculture, Washington, D.C., by Argonne National Laboratory, Argonne, Illinois, September.

Argonne, 2004a, Letter Report: Results of Targeted Groundwater Sampling on the Gerry Dunlap Property and Adjacent Properties at Milford, Nebraska, in December 2003, ANL/ER/AGEM/CHRON-687, prepared for the commodity Credit Corporation, U.S. Department of Agriculture, Washington, D.C., by Argonne National Laboratory, Argonne, Illinois, March 25.

Argonne, 2004b, Final Report: Completion of the Phase II Investigation at Milford, Nebraska Results of Targeted Studies on the Gerry Dunlap Property and Adjacent Properties in December 2003, ANL/ER/TR-04/008, prepared for the Commodity Credit Corporation, U.S. Department of Agriculture, Washington, D.C., by Argonne National Laboratory, Argonne, Illinois, September. 


\section{Appendix A:}

Summary of Investigations in 1999-2003 at the Former CCC/USDA Grain Storage Facility at Milford, Nebraska 


\section{Appendix A:}

\section{Summary of Investigations in 1999-2003 at the Former CCC/USDA Grain Storage Facility at Milford, Nebraska}

In 1995, carbon tetrachloride contamination was detected by the Nebraska Department of Health and Human Services in a drinking water well (the Trojan well) located approximately $1.25 \mathrm{mi}$ south of Milford, Nebraska, and about $300 \mathrm{ft}$ east of the former location of a grain storage facility operated previously by the CCC/USDA. Subsequent sampling of private wells in the area by the Nebraska Department of Environmental Quality confirmed the finding of carbon tetrachloride in the Trojan well and also demonstrated low levels of carbon tetrachloride in a livestock well (the Troyer well) about 1,200 ft north of the former CCC/USDA facility.

In 1999-2003, the CCC/USDA conducted a series of phased environmental investigations to characterize the extent of carbon tetrachloride contamination and to assess whether corrective action might be required. These investigations were conducted on behalf of the CCC/USDA by the Environmental Science Division of Argonne National Laboratory. Argonne is a multidisciplinary research center operated by UChicago Argonne, LLC, for the U.S. Department of Energy (DOE). The CCC/USDA has entered into an agreement with the DOE, under which Argonne provides technical assistance to the CCC/USDA with environmental site characterization and remediation at its former grain storage facilities.

Access restrictions limited the scope of the investigations at Milford. This appendix summarizes the investigations conducted in 1999-2003. Complete analytical data were included in the cited investigation reports.

\section{A.1 Work Plan for Phase I Investigation, 1999}

In preparation for the Phase I field investigation at Milford, a preliminary hydrogeologic model was developed by appraising the existing site data in a regional geologic, hydrogeologic, and hydrogeochemical framework. This conceptual model was used to plan the Phase I field investigation (Argonne 1999), which involved cone penetrometer (CPT) work, hollow-stem auger drilling, mud rotary drilling, a high-resolution shear wave seismic reflection survey, soil and groundwater sampling, and water level measurements. The goals of the Phase I investigation 
were to (1) test and refine the preliminary conceptual model in order to identify the contaminant migration pathways in the study area and (2) develop a preliminary understanding of the occurrence and migration of carbon tetrachloride in the vadose zone and aquifer system.

\section{A.2 Phase I Investigation, 1999}

The Phase I field investigation was conducted in June-July 1999 (Argonne 2000). This work determined that the basic geologic and hydrogeologic setting of the local groundwater system consists of Pleistocene unconsolidated sands, silts, and clays overlying Upper Cretaceous bedrock limestones and shales. A single unconfined aquifer was identified in the shallow unconsolidated sands and silts. A deeper confined aquifer identified within the underlying bedrock limestones is hydraulically isolated from the shallow aquifer. The Phase I studies indicated that carbon tetrachloride contamination in the groundwater at Milford is restricted to the shallow aquifer.

Sampling during Phase I resulted in the following findings:

- Near-surface soil sampling at 45 locations on the former CCC/USDA property indicated carbon tetrachloride contamination on the property's eastern, southern, and western boundaries. Additional sampling was planned for the Phase II investigation to further delineate the lateral extent of contamination.

- Vertical-profile soil sampling at 1 location (SB10) on the former CCC/USDA property, conducted in conjunction with coring to evaluate the conceptual model, indicated subsurface contamination in the vadose zone. Additional soil borings on the property were planned for Phase II, after completion of the near-surface soil survey.

- Geology, hydrogeology, and hydrogeochemistry were investigated at 15 locations near the former CCC/USDA facility. Four seismic lines were run for mapping between the locations. Six temporary wells or piezometers were installed, and eight preexisting private wells were sampled. Additional locations for groundwater sampling in the Pleistocene aquifer were planned 
for Phase II to further delineate the nature of the aquifer and the pathway to sediments adjoining the Big Blue River.

- Shallow groundwater sampling approximately $400 \mathrm{ft}$ west of the Big Blue River at one location (SB03) indicated carbon tetrachloride near the maximum contaminant level of $5.0 \mu \mathrm{g} / \mathrm{L}$, although surface water sampling of the river at two locations found no contamination.

\section{A.3 Interim Phase II Investigation, 1999-2001}

The Phase II Milford investigation began in September 1999 and, because of road construction and access restrictions, continued in January 2000 and September-October 2001. The goals of Phase II were to (1) define and delineate the soil source of contamination at the former CCC/USDA facility and assess the probability that a continuing soil source for groundwater contamination exists and (2) delineate the lateral and vertical extent of the downgradient groundwater plume.

\section{A.3.1 Soil Sampling during Interim Phase II}

Field activities required to address the soil source objective were completed, and their results were documented in an Interim Phase II report (Argonne 2002b). Sampling conducted during Interim Phase II to delineate soil contamination within the former CCC/USDA facility included the following components:

- Near-surface soil sampling at 17 additional locations on the former CCC/USDA property completed the survey begun in Phase I. Residual concentrations of carbon tetrachloride were identified in shallow soils in both the western and eastern portions of the former CCC/USDA facility. The highest levels (> $100 \mu \mathrm{g} / \mathrm{kg}$ ) were near the two original Quonset huts that remain on the property. These observations confirmed an association of carbon tetrachloride contamination with soils at the former CCC/USDA facility, and they indicated that the probable source of carbon tetrachloride contamination to the groundwater existed primarily in the eastern portion of the former facility (Figure A.1). 
- Subsurface soil sampling at 9 locations (SB19, SB25-SB28, SB38-SB39, SB41-SB42) on the former CCC/USDA property detected relatively low levels (up to $70 \mu \mathrm{g} / \mathrm{kg}$ ) of carbon tetrachloride in the upper vadose zone loess soils in the western portion of the facility, generally to a depth of $25 \mathrm{ft}$ BGL, but little or no contamination within approximately $30 \mathrm{ft}$ of the water table in this area. Near the existing Quonset huts in the eastern portion of the property, however, concentrations in several borings were higher (up to $117 \mu \mathrm{g} / \mathrm{kg}$ ) and remained elevated to the bottoms of the borings (Figure A.2). Carbon tetrachloride concentrations exceeding $300 \mu \mathrm{g} / \mathrm{L}$ were also identified in groundwater directly beneath the former facility. The concentrations found in eastern subsurface soils and groundwater indicated that a probable continuing soil source remains at the former facility (Figure 2.1).

\section{A.3.2 Groundwater and Surface Water Sampling during Interim Phase II}

Studies required to delineate the groundwater plume could not be completed in 2001 because of continuing access restrictions. Mapping of the carbon tetrachloride distribution in groundwater performed at that time indicated that a broad contaminant plume originated beneath the former CCC/USDA facility and extended toward the Big Blue River, passing beneath property owned by Mr. Gerry Dunlap. The inferred central, most highly contaminated portion of the plume could not be sampled. Limited sampling on the Dunlap property prior to access refusal suggested that the Pleistocene aquifer under the property might be a single, vertically continuous sand unit, without the low-conductivity silt and clay material noted elsewhere, offering a preferred pathway for lateral transport. Without additional sampling, neither confirmation of the hydrogeology of the aquifer at this location nor accurate delineation of the heart of the plume could be accomplished.

Sampling conducted during Interim Phase II to delineate groundwater contamination resulted in the following findings:

- Groundwater sampling occurred at 29 locations in the investigation area, including 3 private wells, 6 wells or piezometers installed in Phase I and resampled in Interim Phase II, and 20 new locations. In sampling attempted at 4 additional locations, no groundwater could be retrieved. 
- Surface water sampling at 15 locations along the Big Blue River (SW01SW15) indicated that groundwater in the Pleistocene aquifer is discharged near the river or directly into the river. Water collected from the spring at SW08 contained carbon tetrachloride at $7.8 \mu \mathrm{g} / \mathrm{L}$, but no contamination was detected in the resulting surface water drainage sampled from a downslope gully at location SW05. A sample from location SW10 (a seep on the bank of the river) contained carbon tetrachloride at $1.4 \mu \mathrm{g} / \mathrm{L}$.

\section{A.4 Site Monitoring, 2002}

Because access restrictions precluded full delineation of the contaminant plume and complete testing of the hydrogeologic model, two sampling events were conducted to monitor potential expansion of the plume toward the Big Blue River at monitoring locations outside the Dunlap property. Sampling included the following components:

- Groundwater sampling of 8 monitoring wells in June 2002

- Groundwater sampling of 8 monitoring wells in September 2002

- Surface water sampling at 3 locations (SW04, SW07, SW16) along the Big Blue River in September 2002

\section{A.5 Completion of Phase II Investigation, 2003}

In December 2002, access to the Dunlap property was granted for additional groundwater sampling for a limited period. In April 2003, Argonne presented recommendations to the CCC/USDA for targeted groundwater and surface water sampling, as well as electronic sensor profiling and coring of soil, at selected locations on the Dunlap property and on adjacent properties. The purpose was to complete characterization of the site hydrogeology and delineation of the carbon tetrachloride plume. With the CCC/USDA's approval and the consent of the farm manager, the investigation was conducted in December 2003, following the fall harvest. The final Phase II investigation report was completed in September 2004 (Argonne 2004b). Findings of activities conducted to complete the Phase II site characterization included the following: 
- Groundwater levels were measured in the network of monitoring wells and piezometers established during the Phase I and Phase II investigations to determine the direction and gradients of groundwater flow. A semi-radial pattern of groundwater flow was indicated from the vicinity of the former CCC/USDA facility toward the Big Blue River, roughly mimicking the local surface topography (Figure 3.1).

- Argonne's track-mounted (crawler) CPT vehicle was used at 11 locations to investigate the characteristics of the hydrogeologic system controlling groundwater and contaminant migration at the site. Electronic logs of tip, sleeve, and conductivity data were acquired at each location for correlation of saturated intervals with lithologies observed during coring. The results of the targeted sampling on the Dunlap property confirmed that the shallow aquifer is continuous beneath the Dunlap property and is present throughout the investigation area west of the Big Blue River channel. The lithologic properties of the unit vary; to the east, the fine to medium, fairly well sorted sands found in the immediate vicinity of the former CCC/USDA facility decrease in abundance and become more poorly sorted and silty to clayey (Figure A.3).

- Aquifer slug tests were performed to provide data on the hydraulic properties of the aquifer sediments beneath the Dunlap property. The combined geologic and hydrogeologic data for Milford indicate that groundwater flow and contaminant migration will occur preferentially within the thicker saturated sands directly east of the former CCC/USDA facility, then subsequently through less permeable materials toward the Big Blue River in response to the relatively higher hydraulic gradients observed in this direction. Groundwater flow and contaminant migration to the northeast of the former facility are also expected, but the lower abundance of saturated permeable materials and local influences of the bedrock topography in this direction make this pathway less effective.

- Groundwater sampling of monitoring wells and CPT locations indicated a broad carbon tetrachloride plume in the shallow aquifer, originating from the former CCC/USDA facility and extending eastward and northeastward toward 
the Big Blue River. A relatively narrow lobe of contamination to a maximum of $1,700 \mu \mathrm{g} / \mathrm{L}$ extended beneath the Dunlap property to within several hundred feet of the Big Blue River. A second, wider lobe of contamination to a maximum of $99 \mu \mathrm{g} / \mathrm{L}$ extended northeastward beneath the western and northern portions of the Dunlap property. Carbon tetrachloride contamination was not detected beneath the southern part of the Dunlap property (Figure 2.1).

- High levels of chloroform (Figure 2.2) and low levels of methylene chloride (or dichloromethane) observed at several locations suggested that natural bioremediation of the carbon tetrachloride had occurred on at least a localized scale.

- Surface water sampling at 4 locations (SW03, SW04, SW08, and SW19) along the Big Blue River demonstrated that while no carbon tetrachloride had yet been detected during sampling from the river, discharge of contaminated groundwater was occurring via diffuse seepage or more discrete springs along the banks and low-lying areas near the river. The contaminant level at the SW08 spring (along a creek west of the river; Figure 2.1) increased from $7.8 \mu \mathrm{g} / \mathrm{L}$ in 2001 to $11 \mu \mathrm{g} / \mathrm{L}$ in 2003. 


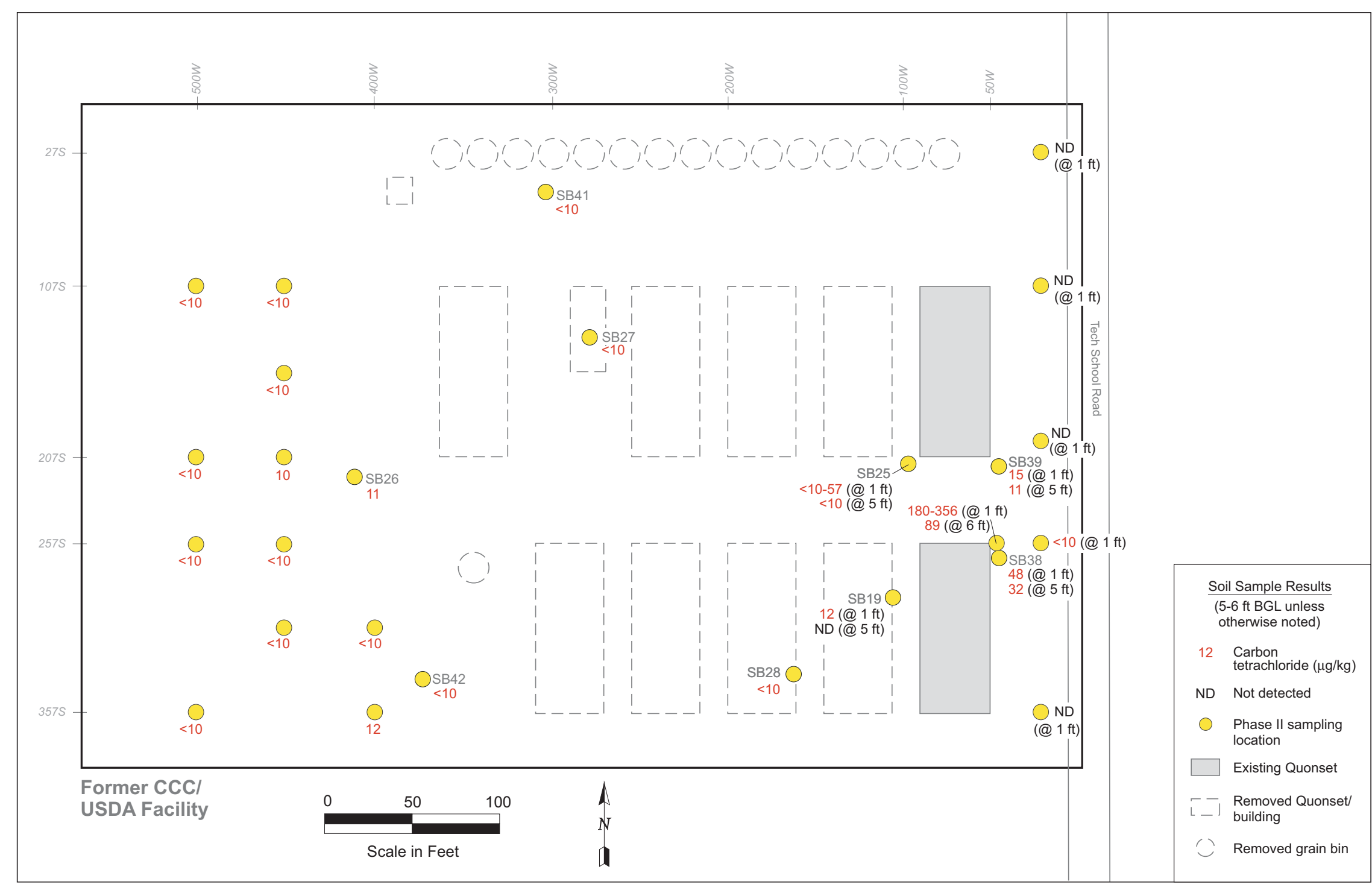

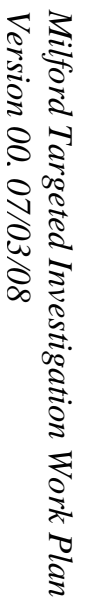

FIGURE A.1 Analytical results for shallow soil samples collected during the Interim Phase II investigation. 


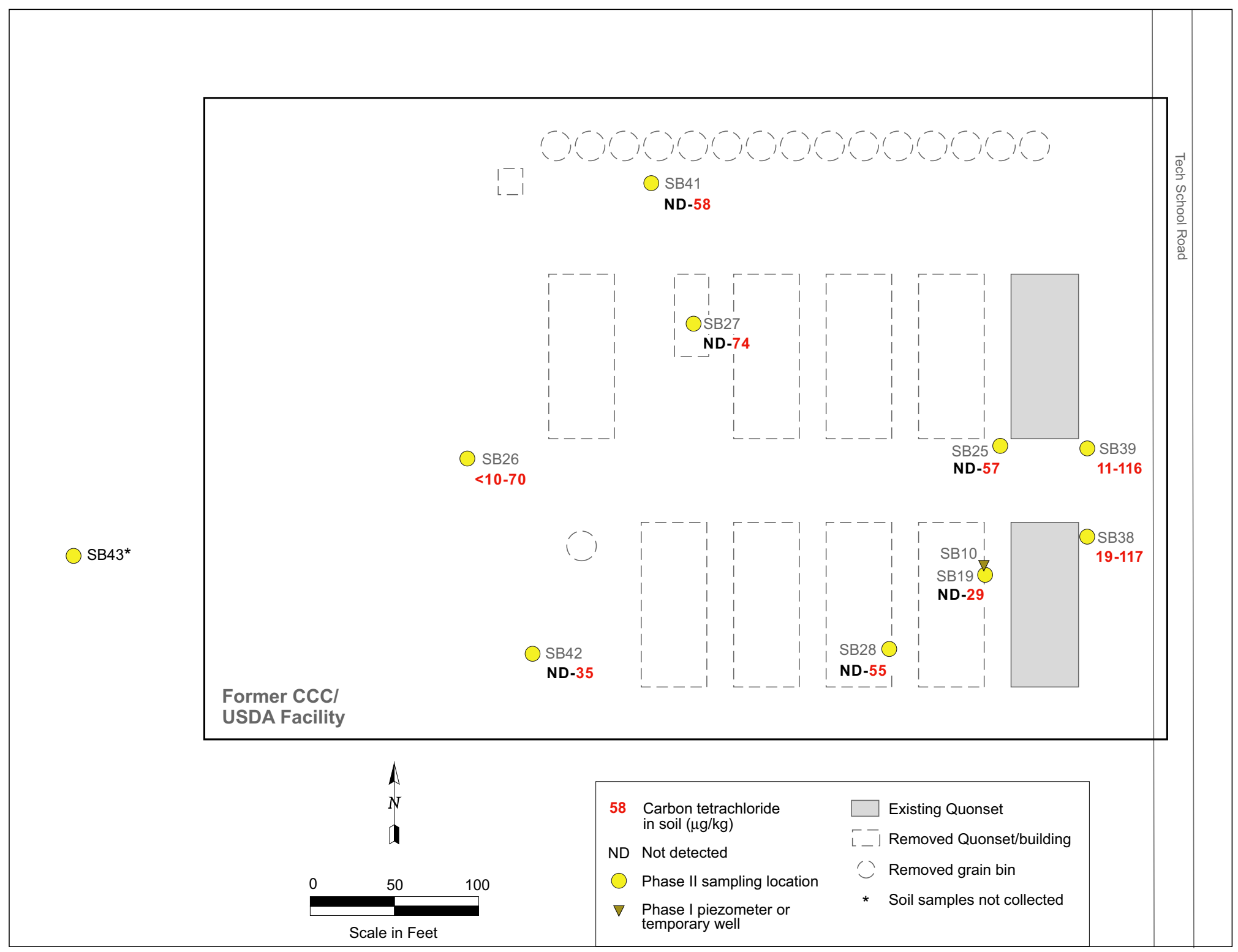

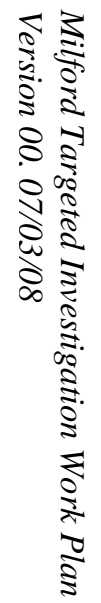

FIGURE A.2 Analytical results for subsurface soil samples collected during the Interim Phase II investigation. 


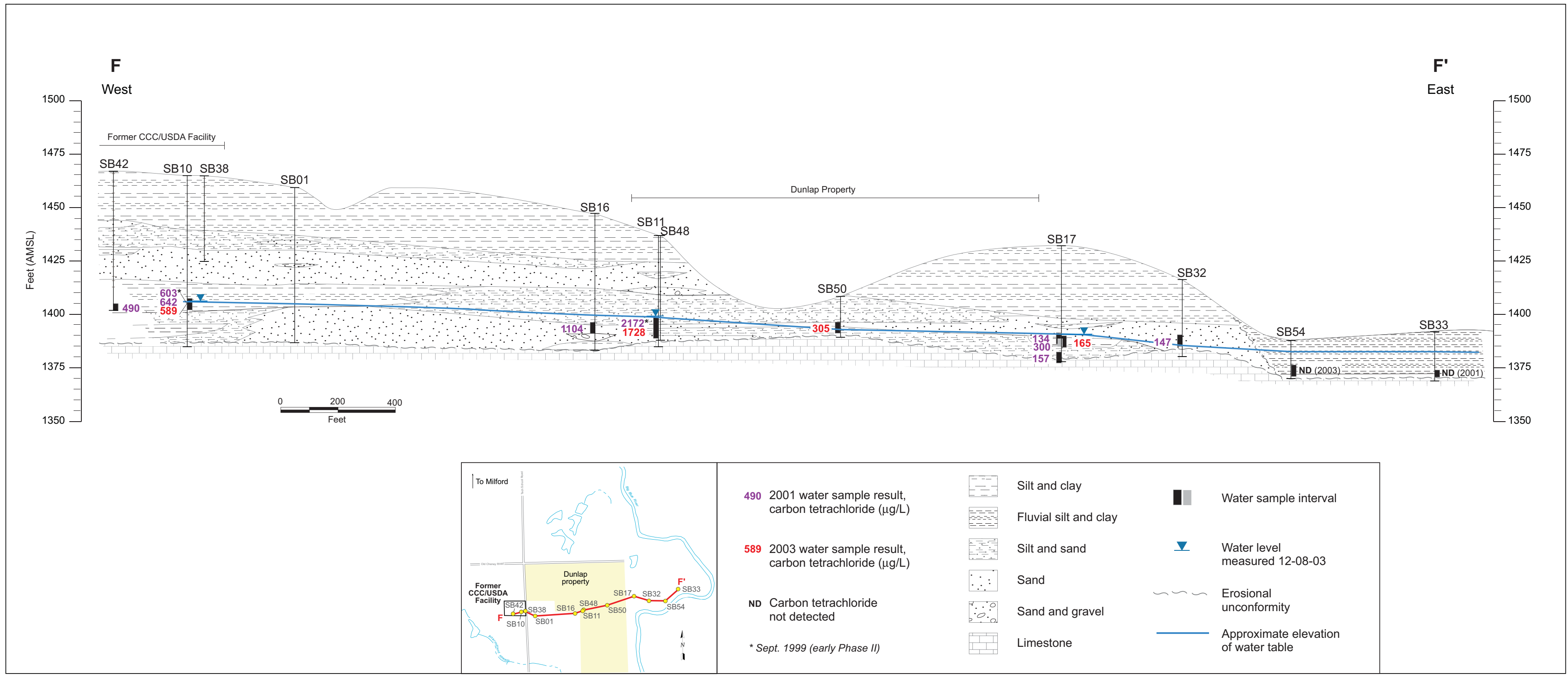

FIGURE A.3 Maximum carbon tetrachloride concentrations in groundwater samples collected at Milford in 1999, 2001, and 2003, displayed on a west-to-east hydrogeologic cross section (vertically exaggerated) running along the axis of the most contaminated part of the plume. 
Argonne

Environmental Science Division

Argonne National Laboratory

9700 South Cass Avenue, Bldg. 203

Argonne, IL 60439-4843

www.anl.gov

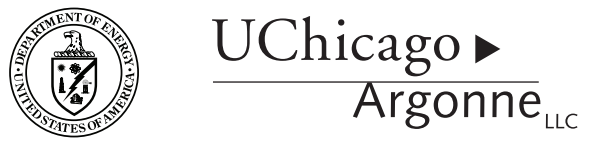

A U.S. Department of Energy laboratory

managed by UChicago Argonne, LLC 